Hohmann S., Mouradian C., Serrano S., Thorez J. (dir.), 2014, Development in Central Asia and the Caucasus - Migration, Democratisation and Inequality in the Post-Soviet Era, London - New York, I.B. Tauris, pp. 215 - 241.

\title{
The post-soviet space between north and south: Discontinuities, disparities and migrations
}

Julien Thorez

Géographe

Chargé de recherche au CNRS

UMR 7528 Mondes iranien et indien

julien.thorez@cnrs.fr

Organization of the post-Soviet space has been fundamentally and permanently transformed since the collapse of the USSR '. A 'territorial transition' was sketched in the context of a diversificationof actors in the political, economic and social fields, be it at state level, entrepreneurial or informal, national or international ${ }^{2}$. Marked by dynamics of fragmentation, disintegration, but also integrationand unification, this process has been redrawing the map of Europe and Asia ${ }^{3}$. Depending on the regions and scales, these spatial dynamics give rise to a heterogeneous territory where both countries integrated into the European Union and countries linked to Western and Southern Asia co-exist now around Russia.

In this context, the restructuring of the means of production in times of economic crisis, the liberalization of exchange based on offer and demand and redefining the geopolitical balance modified the position of countries of Central Asia and the Caucasus within the global arena. In the bipolar world, as a Soviet region, Central Asiawas generally perceived to be in the 'developed world' in scientific works ${ }^{4}$ and expert reports ${ }^{5}$, although some works questioned its inclusion in the "third-world" ${ }^{6}$. For many, the unity of the Sovietspace, based on the centre-periphery model, outweighed regional inequalities although Central Asia was sometimes considered to be a "dominated periphery" 7. Twenty years on from the commencement ofthe 'transition' and in the context of a global world, Central Asian and Caucasian countries are associated with the idea of the "South", irrespective of the different paths taken ${ }^{8}$. This "third-worldization", an original evolution by all accounts, results from the magnitude ofthe economic and social crisis that followed the disintegration of the USSR ${ }^{9}$. But this idea is also based on a classic post-colonial analysis of the post-Soviet space, the frontier between "North" 
and "South" corresponding in almost all publications to the Southern border of the former metropole, Russia ${ }^{10}$.

Table 1: GDP Growth (1991-1996) (in Per Cent)

\begin{tabular}{|l|c|c|c|c|c|c|}
\hline & $\mathbf{1 9 9 1}$ & $\mathbf{1 9 9 2}$ & $\mathbf{1 9 9 3}$ & $\mathbf{1 9 9 4}$ & $\mathbf{1 9 9 5}$ & $\mathbf{1 9 9 6}$ \\
\hline Estonia & -8.0 & -21.2 & -5.7 & -1.6 & +5.0 & +5.0 \\
\hline Latvia & -12.6 & -32.1 & -5.0 & +2.2 & -0.9 & +3.8 \\
\hline Lithuania & -5.7 & -21.3 & -16.2 & -9.8 & +3.3 & +5.2 \\
\hline Belarus & -1.2 & -9.6 & -7.6 & -11.7 & -10.4 & +2.8 \\
\hline Moldova & -16.0 & -29.1 & -1.2 & -30.9 & -1.4 & -5.2 \\
\hline Ukraine & -8.4 & -9.7 & -14.2 & -22.9 & -12.2 & -10.0 \\
\hline Russia & -5.0 & -14.5 & -8.7 & -12.6 & -4.1 & -3.6 \\
\hline Armenia & -11.7 & -41.8 & -8.8 & +5.4 & +6.9 & +5.9 \\
\hline Azerbaijan & -0.7 & -22.6 & -23.1 & -19.7 & -11.8 & +1.3 \\
\hline Georgia & -21.1 & -44.9 & -29.3 & -10.4 & +2.6 & +11.2 \\
\hline Kazakhstan & -11.0 & -5.3 & -9.2 & -12.6 & -8.2 & +0.5 \\
\hline Kyrgyzstan & -7.9 & -13.9 & -15.5 & -20.1 & -5.4 & +7.1 \\
\hline Uzbekistan & -0.5 & -11.2 & -2.3 & -5.2 & -0.9 & +1.7 \\
\hline Tajikistan & -7.1 & -29.0 & -16.4 & -21.3 & -12.4 & -16.7 \\
\hline Turkmenistan & -4.7 & -5.30 & -10.0 & -17.3 & -7.2 & -6.7 \\
\hline
\end{tabular}

Source: World Bank (www.data.worldbank.org).

This analysis is also based on the identification of characteristics of post-colonial situations: the expansion of landlockedness as a result of the internationalization of former inter-republican Soviet borders ${ }^{11}$; the increase in migrations of imperial populations to their homeland ${ }^{12}$; and the boom in labour migration towards the former metropole ${ }^{13}$. A new geography of development thus takes form in apost-Soviet world where, between "North" and "South", societies and territories are changing, in the context of increasing socio-political inequalities and transformation of practices of mobility.

\section{Crisis and Inequalities: From East to South}

\subsection{Crisis and Impoverishment: The Third-Worldization of the Ex-USSR?}

The division of the USSR into 15 independent and sovereign countries did not just signify the fracturing of a political territory. This 'spatial event' led to a long-term change in territorial organization by creating an area fundamentally different to its previous state ${ }^{14}$, and coincided with the questioning of regional geo-economic gradients as the post-Soviet transformation commenced with an exceptional economic and social crisis (Table 1). At the turn of the 1990s, the disintegration of the Soviet production and 
exchange system, the adoption of principles of the market economy, as well as international opening, all had a far- reaching and long-term effect on national economies. From 1991 to 1994, the GDP of all post-Soviet countries decreased annually. This propagation of the crisis reveals the importance of interdependent relations created by Soviet planning. During this period of "chaos" ${ }^{15}$, the GDP of Uzbekistan, for whom the economy was officially less destabilized than others, fell by 20 per cent, whereas Estonia and Russia witnessed a 30 per cent reduction and Georgia, where the crisis was even more exacerbated, almost 80 per cent (Table 1). The geography of the independent states was initially coined a "geography of crisis" ${ }^{16}$ combining industrial decline, an explosion in unemployment rates and impoverishment of the majority of the population 17.

Most Baltic and Caucasian countries recorded positive growth from 1994-95, whereas the crisis continued to the end of the 1990s in Russia, Moldova and Ukraine. In addition, the recovering economic growth did not equate to post-Soviet countries returning quickly to pre-crisis levels. The GDP calculated in current dollars did not surpass 1990 levels before 2002 in Armenia, 2003 in Kazakhstan, 2004 in Russia and 2008 in Tajikistan. During the first years of independence, countries of the former USSR thus suffered from an unprecedented decrease of their position in regional and global hierarchy, since world growth increased on average by 3 per cent per annum from 1990 to 1999 , according to the IMF. In this regards, the post-Soviet situation is not comparable to that of "post-colonial Western Europe" as the period of independence corresponded to rapideconomic growth in Africa and Western Europe ${ }^{18}$. This said, thecollapse of the post-Soviet economies in a context where international institutions such as the IMF and the World Bank were increasingly present ${ }^{19}$ justified the status change regarding CIS countries in the globalized world and their integration into the category of "emergingand developing countries".

In Central Asia and the Caucasus, this trend could be reinforced by the landlockedness that accompanied the end of imperial territorial construction. This geographical situation has caused a political dependence on neighboring transit countries and given rise to an economic growth deficit in contrast to littoral countries, sinceexchanges were limited by the inflated continental transit $\operatorname{costs}^{20}$. However, this element had little effect on the economic development of post-Soviet countries, because of the importance of the macroeconomic difficulties. Interestingly, littoral countries, such as Georgia and Ukraine, suffered from the crisis more than neighboring landlocked countries such as Azerbaijan, Armenia or Belarus. The heterogeneity of trajectories in the countries of the former Soviet Union, resulting notably from the political, economic and geo-political decisions of the sovereign authorities, has now a spatial dimension. The post-Soviet world is unequal, segmented as much by new political borders as by economic discontinuities

\subsection{Inherited Inequalities? Central Asia as a Soviet Third World?}

From a territorial organizational standpoint, the socialist political project of the Soviet authorities aimed to reduce regional differences by changing the location of the production and, more generally, to eradicate spatial inequalities by homogenizing national territory and doing away with social classes ${ }^{21}$. The territorial planning policy 
also aimed to unite the Soviet space by creating a uniform territorial gridand developing inter-regional relations that would be stimulated by the territorial division of work ${ }^{22}$. In this context, the unified transport system, whose organizing principles encouraged themovement of goods and people by minimizing transportation costs, should have played an important role by promoting the logics of regional specialization and national homogenization ${ }^{23}$.

Table 2: Annual GDP per Capita (in Dollars) and Country Differences from 1990 to 2010

\begin{tabular}{|l|r|c|c|c|c|c|c|c|c|c|}
\hline & \multicolumn{2}{|c|}{$\mathbf{1 9 9 0}$} & \multicolumn{2}{c|}{$\mathbf{1 9 9 5}$} & \multicolumn{2}{c|}{$\mathbf{2 0 0 0}$} & \multicolumn{2}{c|}{$\mathbf{2 0 0 5}$} & \multicolumn{2}{c|}{$\mathbf{2 0 1 0}$} \\
\hline Estonia & 3,193 & $\mathbf{9 1}$ & 3,030 & $\mathbf{1 0 0}$ & 4,144 & $\mathbf{1 0 0}$ & 10,329 & $\mathbf{1 0 0}$ & 14,341 & $\mathbf{1 0 0}$ \\
\hline Latvia & 2,796 & $\mathbf{8 0}$ & 2,107 & $\mathbf{6 9}$ & 3,301 & $\mathbf{7 9}$ & 6,973 & $\mathbf{6 7}$ & 10,723 & $\mathbf{7 4}$ \\
\hline Lithuania & 2,841 & $\mathbf{8 1}$ & 2,178 & $\mathbf{7 1}$ & 3,297 & $\mathbf{7 9}$ & 7,604 & $\mathbf{7 3}$ & 11,045 & $\mathbf{7 7}$ \\
\hline Belarus & 1,705 & $\mathbf{4 8}$ & 1,371 & $\mathbf{4 5}$ & 1,273 & $\mathbf{3 0}$ & 3,090 & $\mathbf{2 9}$ & 5,765 & $\mathbf{4 0}$ \\
\hline Moldova & 9,72 & $\mathbf{2 7}$ & 477 & $\mathbf{1 5}$ & 354 & $\mathbf{8}$ & 831 & $\mathbf{8}$ & 1,631 & $\mathbf{1 1}$ \\
\hline Ukraine & 1,570 & $\mathbf{4 5}$ & 936 & $\mathbf{3 0}$ & 636 & $\mathbf{1 5}$ & 1,829 & $\mathbf{1 7}$ & 3,007 & $\mathbf{2 1}$ \\
\hline Russia & 3,485 & $\mathbf{1 0 0}$ & 2,670 & $\mathbf{8 8}$ & 1,775 & $\mathbf{4 2}$ & 5,337 & $\mathbf{5 1}$ & 10,440 & $\mathbf{7 2}$ \\
\hline Armenia & 637 & $\mathbf{1 8}$ & 546 & $\mathbf{1 8}$ & 621 & $\mathbf{1 4}$ & 1,598 & $\mathbf{1 5}$ & 3,031 & $\mathbf{2 1}$ \\
\hline Azerbaijan & 1,237 & $\mathbf{3 5}$ & 397 & $\mathbf{1 3}$ & 655 & $\mathbf{1 5}$ & 1,578 & $\mathbf{1 5}$ & 5,718 & $\mathbf{3 9}$ \\
\hline Georgia & 1,611 & $\mathbf{4 6}$ & 569 & $\mathbf{1 8}$ & 692 & $\mathbf{1 6}$ & 1,470 & $\mathbf{1 4}$ & 2,621 & $\mathbf{1 8}$ \\
\hline Kazakhstan & 1,647 & $\mathbf{4 7}$ & 1,288 & $\mathbf{4 2}$ & 1,229 & $\mathbf{2 9}$ & 3,771 & $\mathbf{3 6}$ & 9,132 & $\mathbf{6 3}$ \\
\hline Kyrgyzstan & 609 & $\mathbf{1 7}$ & 364 & $\mathbf{1 2}$ & 280 & $\mathbf{6}$ & 476 & $\mathbf{4}$ & 847 & $\mathbf{6}$ \\
\hline Uzbekistan & 651 & $\mathbf{1 8}$ & 586 & $\mathbf{1 9}$ & 558 & $\mathbf{1 3}$ & 547 & $\mathbf{5}$ & 1,381 & $\mathbf{9}$ \\
\hline Tajikistan & 496 & $\mathbf{1 4}$ & 213 & $\mathbf{7}$ & 139 & $\mathbf{3}$ & 358 & $\mathbf{3}$ & 820 & $\mathbf{5}$ \\
\hline Turkmenistan & 881 & $\mathbf{2 5}$ & 558 & $\mathbf{1 9}$ & 645 & $\mathbf{1 5}$ & 1,707 & $\mathbf{1 6}$ & 3,967 & $\mathbf{2 7}$ \\
\hline
\end{tabular}

Source: World Bank

Despite these principles, the territorial planning policy of the USSR, often oscillating between sectorial and territorial approaches, succeeded in creating a unified space, but it failed to eradicateregional inequalities ${ }^{24}$. On the contrary, while sector administrations privileged already developed regions, the gap in development grew slowly towards the end of the Soviet era to the detriment of the Southern republics of Central Asia, according to official indicators ${ }^{25}$. As a consequence, the GDP per capita in 1990 varied considerably between Soviet Socialist Republics, from 496 dollars in Tajiki stan to 3,485 dollars in Russia (Table 8.2). The Soviet planned system's organization involved a territorial concentration of power, despite a real autonomization of the Soviet Socialist Republics, particularly in the Brejnev era. And the Soviet territory was structured in terms of a centre-periphery gradient, which reflected the imbalance of politicaland economic relationships ${ }^{26}$.

At the level of the Soviet Union, the political centre included the wealthiest regions whereas the republics furthest removed from the heart of the Soviet territory were also the poorest. Inequalities were in part a result of the varied development of the production system. In the planned production and exchange organization, Central Asia 
contributed to the supply of raw materials (minerals, hydrocarbons, cotton,wool, etc.) for the Western regions of the USSR (Volga, Urals, Central Russia, the Baltics, Belarus, etc.) but remained relativelynon-industrialized, save for the expansion of some industrial poles like Tashkent, Alma-Ata and Karaganda ${ }^{27}$. Yet the transfer of funds by the authorities to the peripheries, representing 20 per cent of national income in Tajikistan and Kyrgyzstan, only partially compensated for these regional disparities ${ }^{28}$. To a certain extent, Central Asian societies could also be compared to those of developing countries in the neighboring Iranian world. Despite the relativeearly literacy of Central Asian women, the demographic transition temporality in Central Asia coincided with that of Iran, with reduced birth rates only really starting in the $1970 \mathrm{~s}^{29}$.

The inequalities of the Soviet space were in part a reproduction of spatial disparities under the Tsarist Empire ${ }^{30}$. Although Central Asia caught up significantly during the 20th century, it still reflects thedeficiencies in the Soviet planning policy which failed to localize activities efficiently in order to ensure a homogenous and coherent regional development ${ }^{31}$. However, the centre-periphery model is notrelevant to analyze Soviet Central Asian and Caucasian societies, because these societies were not faced with the poverty that would have been specific to the dominated peripheries ${ }^{32}$ Indeed sociological andeconomic publications of the end of the Soviet period portrayed Central Asian populations benefiting from a quality of life comparable to or better than the populations of European regions of the USSR, particularly in rural areas ${ }^{33}$. Despite small plots - 0.2 hectares inTajikistan and 0.5 hectares in Kyrgyzstan private agriculture ensured substantial revenues for collective farm workers and at the same time contributed to containing underemployment and limiting the cost of living both in the countryside and urban areas. On the eve of the collapse of the USSR, Central Asia, for the most part rural, was faced with a complex and ambivalent situation that highlighted the paradoxes of the path of development and the territory of the Soviet Union.

\subsection{Increased Spatial Inequalities: When the "South" separates from the "North"}

In addition to changes to the political map, the "territorial transition" is marked by an increase in socio-spatial differences. In the first years of the post-Soviet crisis, territorial inequalities were reinforced between the newly independent countries, but also between regions, between cities and the countryside, between cities and between neighborhoods. According to World Bank data, the wealth differences between Soviet republics, on the basis of GDP per capita per annum, ranged from 1 to 7 in 1990. By 2000, a difference of 1 to 29 separated Tajikistan and Estonia, with respective GDP per capita per annum of 139 and 4,144 dollars (Table 2). In the 2000s, this difference became slightly less significant due to the rapid economic growth of Central Asian and Caucasian countries which was in particular based on the expansion of raw material production (oil, gas, minerals, etc.). In 2010, GDP per capita per annum reached 820 dollars in Tajikistan, but it exceeded 14,000 dollars in Estonia, bringing the difference to 1 to 17 . Over the past 20 years, disparities between post-Soviet countries have thus significantly increased from a social and economic viewpoint, in addition to their diverse geopolitical orientations. The Baltic States, members of the EU since 2004, have thus integrated into the European space and the 'triad' despite being poorer than the average EU country, while at the opposite end of the spectrum, Tajikistan and Kyrgyzstan show 
economic indicators comparable to those of sub-Saharan African countries. Consequently, the significant increase in spatial inequal- ities resulted in a radical geoeconomic division of the post-Soviet space between countries of the "North" and the "South".

Despite the downgrading of Central Asian and Caucasian countries in the 1990s, likened to a "third-worldization", the differences in wealth do not correspond to the classic situation between a "former metropole" and "former colonies" as seen in Western European post-colonial configurations. Firstly, Russia has not the highest GDP per capita per annum, despite clearly being the strongest economy in the region with a GDP of 1,479 billion dollars in 2010 (Table 3). Furthermore, the main economic discontinuities are not located on the Southern borders of Russia but on the Southern borders of Kazakhstan (Map 1). Despite the continuation of a centre-periphery logic though imperfect - this observation confirms the specific situation of Kazakhstan within the post-Soviet space. Kazakhstan is not only the sole Central Asian state member of the Common Economic Space (CES), founded with Russia and Belarus in 2012. It is now the second regional economic power. This further highlights the difficulty in locating the North -South border, which is still commonly defined by internationalorganizationsandresearchersasthelimitbetweenRussiaandCentralAsiaand theCaucasus ${ }^{34}$.

Table 3: GDP of Post-Soviet Countries in 2010 (in Millions of US dollars)

\begin{tabular}{|l|c|l|c|}
\hline Estonia & 19.2 & Armenia & 9.3 \\
\hline Latvia & 24.0 & Azerbaijan & 54.7 \\
\hline Lithuania & 36.3 & Georgia & 11.6 \\
\hline Belarus & 54.7 & Kazakhstan & 149.0 \\
\hline Moldova & 5.8 & Kyrgyzstan & 4.6 \\
\hline Ukraine & 137.9 & Uzbekistan & 38.9 \\
\hline Russia & $1,479.8$ & Tajikistan & 5.6 \\
\hline & & Turkmenistan & 20.0 \\
\hline
\end{tabular}

Source: World Bank

But despite this significant divide between the wealthiest and poorest countries, locating the North-South border seems to be a difficult guest, because spatial inequalities have increased at every scale. In all countries, the organization of space was locally transformedwith the appearance of numerous "crisis funnels" andsome "oases of prosperity" ${ }^{35}$.

At the national level, this increase in territorial disparities has deepened regional inequalities. For example within Kazakhstan, GDP per capita per annum currently varies from 1 to 10 depending on the region ${ }^{36}$. The oblasts of Zhambyl and Southern Kazakhstan contrast with the wealthy oil regions of Atyrau and Mangystau, and with the cities of Astana and Almaty, respectively the political and economic capitals of the country ${ }^{37}$. This indicator highlights a lack of cohesion in Kazakhstan's economic space. This is also assessed by the average salary, which varies considerably between the oblasts in question, from 1 to 4 , even if these two indicators provide imperfect 
information on the real quality of life of the population ${ }^{38}$.

In each country, the increasing gap between the countryside and cities, from an economic and social standpoint, is also reflecting the fragmentation of the national space, and constitutes an incentive for migration towards principal agglomerations. Whereas numerous rural areas suffer from peripherization, cities, with Moscow at the fore, benefit from metropolization. Contrary to small and medium- sized towns, often sorely affected by the post-Soviet crisis, cities concentrate political functions, polarize investments, lure wealth andwitness the development of their role in the territorial system ${ }^{39}$. Thespaces within these cities also become differentiated due to a combination of socio-spatial aggregation and segregation processes resulting from the liberalization of the real estate and land market ${ }^{40}$. Gated communities made up of large individual houses reserved for the political and economic elite have been erected on the peripheries of the main agglomerations and a gentrification of the city centres can also be noted. Inversely, several cities, such as Bishkek and Almaty, have witnessed the spontaneous and illegal erection of residential neighbourhoods close to the microrayon, the vast residential areas built during the Soviet period.

While the Soviet plan sought to eradicate spatial inequality, the political, economic and social transition, which varied from one country to the next, accentuated territorial differences, commensurate with the growth in social inequalities ${ }^{41}$. This new geographicaldistribution of wealth, which reflects the political paradigm of capitalist orientation adopted by post-Soviet governments, representsone of the main forms of spatial injustice ${ }^{42}$. Yet the territorialplanning policies carried out by post-Soviet states rarely sought to reduce territorial inequalities, despite some redistribution mechanisms of the profits from raw materials, which filter down through national territories, in particular via subsidized energy prices ${ }^{43}$. Besides the statehood crisis of the 1990s and their liberal economic orientations, the authorities privileged the "territorial construction of independence", that is adapting territorial organization to the new status of independent and sovereign state by redefining borderfunctions, adapting networks to the new borders or nationalizing the capitals or the places of power ${ }^{44}$. In addition no regional institution isnow in a position to lead territorial policies at the level of the postSoviet region. Thus, 20 years after the end of the USSR, political borders, economic discontinuities and social barriers reflect in the territorial organization the implementation by national elites of strategies of social and political differentiation and domination. At all levels, these discontinuities split up a region now situated between North and South along the principal divide of today's world, and following an exceptional economic crisis in the 1990s.

\section{The Emergence of a Post-colonial Space?}

The territorial organization that emerged from the post-Soviet transition presents a significant contrast with Western European post-colonial situations, be it inherited from the Soviet period or resulting from the diverse paths taken by the newly independent countries (supra). Though it can be argued that the creation of an international migration field between Central Asia and Russia, sparked by the sheer number of labour migrants from South to North, is similar to relations between Africa, Asia and Western Europe since decolonization. 


\subsection{An Accessible "Metropole": The Boom in Labour Migrations to Russia}

Two decades after the disintegration of the USSR, several million Central Asian nationals work on a seasonal, temporary or sometimespermanent basis in Russia where they make up almost half of the immigrant workforce ${ }^{45}$. In 2008, between 6 and 7 million labourmigrants were employed in Russia, including 2.425 million with work permits $^{46}$. Among these migrants, approximately 2 million originated from Uzbekistan, 1 million from Tajikistan and 0.5 million from Kyrgyzstan ${ }^{47}$. Labour migration is a major social andeconomic reality in contemporary Central Asia, Turkmenistan aside. But it developed only in the mid-1990s in Tajikistan, at the end of the decade in Kyrgyzstanand at the beginning of 2000 s inUzbekistan ${ }^{48}$. This labour migration, including a flow towardsKazakhstan, is proof of a radical change in the territoriality of Central

Asiansas, priortothe1990s, theirmigratorymobilitywasthelowestoneintheSovietpopulat ion,despiteencouragementfromSovietauthorities atthe time ${ }^{49}$.

The emergence of new migratory practices reflects the economic and social situation of Central Asian countries and the "third- worldization" after the collapse of the USSR, although the elementswhich frame the demand for mobility are extremely complex ${ }^{50}$. Theemigration of the workforce and the extraversion of the accumulation of capital materialize individual and family strategies to overcome economic difficulties in a situation where the average monthly wage is no more than 100 dollars in Tajikistan and 200 dollars in Kyrgyzstan (Table 4).

A classic case scenario, the poorest cannot mobilize resources needed to migrate although this part of the population suffer full exposure to employment market tensions provoked by a lengthyeconomic depression coupled with strong demographic growth $^{51}$.InTajikistan, the population reached 7.565 million according to the 2010 census, compared to 5.092 million in 1989. In Uzbekistan, the workforce went from 10.2 million in 1990 to 14.8 million in 2006due to the arrival on the market of the generation born during thebirth rate peak of the $1980 \mathrm{~s}^{52}$.Although living belowwhat they would deem a satisfactory level, the majority of the population has sufficient economic and social capital to start a migratory path towards Russia. Despite the xenophobic and racist environment, Russia remains an attractive option for migrants because of its strong economic growth after the 1998 crisis, its demographic subdued growth and its cultural proximity.

Table 20: Average Salary in CIS Countries in 2012 (in dollars).

\begin{tabular}{|l|l|l|c|}
\hline Russia & 795 & Georgia & 327 \\
\hline Kazakhstan & 625 & Armenia & 286 \\
\hline Azerbaijan & 469 & Moldova & 268 \\
\hline Belarus & 360 & Kyrgyzstan & 208 \\
\hline Ukraine & 339 & Tajikistan & 110 \\
\hline
\end{tabular}

Source: Committee of Statistics of the CIS 
Like economic dissatisfaction, the unequal geographical distribution of wealth stimulates demand for migration from national to internationallevel, although the relative closing of the post-Sovietborders at the same time appears to hinder regional circulation ${ }^{53}$.Theincrease in the difference in salaries during the transit ion (Table 4) encourages migrations, even though migrants from Uzbekistan,Kyrgyzstan and Tajikistan do not claim the same salary as their Russian counterpart for the same job $^{54}$.Central Asian migrants arepaid between one-third and one-half of a Russian worker's salary but try to make up for it by working more. On average, the migrant working week is 20 hours longer than Russian workers and in a third of cases exceeds 70 hours ${ }^{55}$. As such, migrant worker salaries can equal those of the Russians and exceed by far the average salary paid in their country of origin.

Entry to Russia for Central Asian nationals is (in theory) relatively easy from a legal perspective. The agreement signed by CIS countries in Bishkek in 1992 officially grants their citizens free movement within the post-Soviet space. Inpractice, Russian legislation provides that nationals from Kyrgyzstan, Uzbekistan and Tajikistan can enter the national territory without a visa and, after registering, can stay for 90 days with a temporary residency authorization (vremennoe pribyvanie) (Figure 1). However, it is much harder to obtain a work permit, due to annual quota fixed by the authorities, or getthree- or five-yearresidence permits. Consequently, the majority of Central Asian migrants work illegally in Russia ${ }^{56}$.Russia nevertheless appearsaccessible from Central Asia, with multilateral agreements introducing real fluidity within a politically fragmented post-Soviet space. In this sense, the status of the new borders between Central Asia and its former metropole differs considerably from the Southern borders of the European Union, which are in some cases materialized by a wall and play a significant role in migration policy, aiming at controlling andlimiting access of migrants from the South to the territory of Europe ${ }^{57}$. However in practice, crossing borders and transiting via a foreign country often means difficulties and dangers for migrants ${ }^{58}$.

The accessibility to Russia is largely due to the numerous air, rail and road connections between Central Asia and Russia, operated bycompanies of both sides (infra). This transport supply constitutes a dense and diversified network that facilitates access to Russia for Central Asian migrant workers. Transport costs remain relatively low, particularly in light of the income migrant workers hope to make in Russia, and despite an increase related to post-Soviet restructuring and reduced mobility subsidies for transport companies. In September 2008, a second class train ticket from Tashkent to Saratov cost 140,000 sums (the equivalent of 70 Euros or 105 dollars), from Tashkent to Moscow 260,000 sums (130 Euros or 195 dollars). At the same time, a flight from Tashkent to Ufa, Rostov, Chelyabinsk or Novosibirsk cost 200 Euros (or 280 dollars) 59. Migrants can in addition reduce travel costs to Russia by taking a coach, an uncomfortable and long journey. From Bishkek to large towns in Western Siberia (Novosibirsk, Omsk), the journey takesapproximately 48 hours. In spring 2012, a ticket from Bishkek to Novosibirsk cost 3,250 soms (55 Euros or 70 dollars), from Bishkek to Krasnoyarsk 4,450 soms (75 Euros or 95 dollars), and from Bishkek to Moscow 6,000 soms (100 Euros or 130 dollars). The lack of a financial barrier encourages Central Asian population mobility and a concentration of migration towards Russia. The possibility to travel from Central Asia to Russia legally and cheaply also goes a long way to explaining the seasonal nature of migrant movement, regardless of dependency on weather conditions for certain types of work in Russia (construction, agriculture, 
etc.).

\subsection{From Disintegration to Reactivation: A New Regional Space}

Whereas the initial years of territorial transition were marked by the fragmentation and disintegration of the Soviet space ${ }^{60}$, labour migrations shattered this dynamic and contributed to the creation ofa new regional space. In the 1990s, the end of the unified Soviet transport system led to regional connections being replaced by national and international links. This process was in line with the geopolitical imperatives of newly independent states waiting tointegrate into the globalized world and affirm their sovereignty by reinforcing their unity ${ }^{61}$. Numerous air and rail liaisons ceased to berun by transport operators, who were created after the dismemberment of Soviet companies. On the eve of the collapse of the USSR, 148 trains circulated weekly in both directions between Southern Central Asia and other Soviet regions. Ten years after independence, only 14 weekly trains continued to connect Uzbekistan, Tajikistanand Kyrgyzstan to Russia. It should be noted that Moscow was no longer accessible from Turkmenistan ${ }^{62}$. Rail-related difficulties(reorganization of transit traffic, lack of agreement on tariffs, erection of customs barriers) did not give rise to a modal shift towards air transportation. Quite the opposite, the latter experienced a similar crisis. Regional traffic through Nukus (Uzbekistan) plummeted from140,000 to 14,000 passengers between 1990 and $1993^{63}$. TheAeroflot network between Southern Central Asia and other Soviet regions comprised140 regular connections in 1984 but only 43 were operatedin 1996byRussianand Central Asian companies (Maps 2 -5).

The development of charter flights to a certain extent compensated for the cessation of regular connections, for example Dushanbe- Moscow, but did not have a significant effect on general development. The reduced frequency of flights was accompanied by the shrinking of the geographical coverage of airlines network. This decrease in air and rail links affected relations between Central Asia and Russia as well as between Central Asia, the Caucasus and Eastern Europe. In 1989, Aeroflotoperated 27weeklyflights between Kiev andUzbekistanand 10between Kiev and Tajikistan.By 1994, no companywas flying these routes ${ }^{64}$. This clearly shows that thereduced transport network largely contributed to the simplification of territorial organization and the disintegration of the Soviet space.

Since the end of the 1990s, the process of the deconstruction of Soviet territorial links has decreased and been replaced by a regional reintegration dynamic stimulated by labour migrations. In the context of the normalization and stabilization of transport companies, the transport supply between Central Asia and Russia has increased and diversified to meet the demand for mobility of Central Asian migrant workers. Road links made by coaches, mikroavtobus or even taxis have appeared. In Soviet times, this modeof transport was reserved for short distances ${ }^{65}$. But now dozens ofcoaches cross the Kazakh Steppes on their way to Siberia, the Urals orCentral Russia, in particular fromNorthern Kyrgyzstan and Western Uzbekistan ${ }^{66}$. Air and rail networks have also developed with newliaisons and increased frequencies. 
Table 21: Air links between Uzbekistan and Russia (1984-2008)

\begin{tabular}{|l|c|c|c|c|}
\hline & $\mathbf{1 9 8 4}$ & $\mathbf{1 9 9 6}$ & $\mathbf{2 0 0 2}$ & $\mathbf{2 0 0 8}$ \\
\hline Uzbek cities connected to Russia & 8 & 9 & 8 & 11 \\
\hline Russian cities reachable from Uzbekistan & 30 & 15 & 15 & 17 \\
\hline Lines operated between Uzbekistan and Russia & 53 & 19 & 22 & 36 \\
\hline Lines between Uzbekistan and Moscow & 8 & 5 & 5 & 11 \\
\hline Lines between Uzbekistan and Saint-Petersburg & 3 & 1 & 1 & 6 \\
\hline Lines between Uzbekistan and Minvody & 8 & 1 & 3 & 1 \\
\hline
\end{tabular}

Sources: airlines (Aerojlot,UzbekistanAirways,TajikAir,SrmionAir,AirBishkek,etc), airports.

In 1996, one regular airline existed between Tajikistan and Russia, 11 in 2002 and 29 in 2008 (Maps 5 and 7). Between Uzbekistan and Russia, airlines of the two countries operated 36 regular flights in 2008, as opposed to 19 in 1996 and 22 in 2002 (Table5, Maps 4 and 6).

The geographical expansion of the transport network considerably improved access to Russia and Central Asia. All major cities in Uzbekistan, Tajikistan and Kyrgyzstan are now connected with Russia. Linked only by charters until 2006, Osh airport has now regular flights to eight airports in Russia (Moscow, Novosibirsk, St Petersburg, Kazan, Yekaterinburg, Samara, Krasnoyarsk and Irkutsk). Consequently its international traffic, including passengers to the Chinese town of Urumchi, rose from 25,000 to 271,000 passengers between 2005 and 2010. Despite a slower development rate, rail transport experienced similar changes, in particular from Uzbekistan. Thus, after a short decade of detachment, Central Asia seems to be restoring a coherent spatial entity with Russia, structured by the circulation of persons, goods and capital, and this despite significant territorial inequalities.

Run by Central Asian and Russian companies $^{67}$, the creation ofnewairandraillinksdoesnotcorrespondtoa reproduction of the Soviettransportnetwork.Firstly,theflowremains less intense thaninthe 1980s.Atthattime,twotothreedailytrainsconnected Tashkentto Moscow, whereastodaythisconnection is made fourtimesaweek.Further,the geography of regionalconnectionshaschanged.Ontheonehand,thetrafficincreaseinitiallyfocusedon the CentralAsia-Russia axis, whereas transversal connections to the Caucasusand Eastern Europearerudimentary.In particular, there arenolongerregularflightsfrom TajikistanandKyrgyzstantothe Caucasus orEastern Europe.There are few remaining flights from Tashkent to these destinations. But the quasi-disappearance of transverse air connections contributes to accentuate the polarization around the former Russian metropole of the whole regional transportnetwork. This greatly contrasts with the diversity of regional relations formerly ensured by the Soviet transport system.

On the other hand, air, rail and road services to Russia are reorganized to the detriment of tourist regions and the benefit of industrial areas. Minvody, located at the heart of the large hot springs area in the Northern foothills of the Caucasus, was linked to eight airports in Uzbekistan on the eve of independence. One weekly flight 
now connects it to Tashkent (Table 5, Map 6). Inversely, the airports of Surgut and Nizhnevartovsk, serving the important oil and gas producing region of Western Siberia, are now connected to several towns in Uzbekistan and Tajikistan. Polarized by Moscow, which is the best connected city from Central Asia, the regional transport network has thus fundamentally changed due to the generalization of labour migrations and the decrease in leisure-related mobility. The structural evolution of the transport system is significant of post-Soviet spatial changes: it contributes to ensure the sustainability of a coherent regional space built around Russia, but also to the "move" of Kyrgyzstan, Uzbekistan and Tajikistan towards the South. To this extent, the reorganization of the transport system contributes to reformulating relations between Russia and Central Asia.

\section{Conclusion}

At the end of the post-socialist territorial transition, the development of sociospatial differences in the context of an economic crisis projected the border between the North and the South to the heart ofthe post-Soviet space. Although this boundarydoes not correspond to the borders of the former Russian metropole ${ }^{68}$, this socioeconomicdiscontinuity shapes societies and regional territories based on a centreperiphery model that confirms the third-worldization of Caucasian and Central Asian countries. In this context, the emergence of an international migratory field between Central Asia and Russia corresponds to a classic post-colonial situation, structured on the basis of unbalanced relations between the North and the South. Twenty years after independence, new forms of dominationtraverse the regional geopolitical field, while migrant mobility is accompanied by a large capital circulation. According to the Central Bank of Russia, in 2011, remittances from Russia to Uzbekistan represented 4,909 million dollars, 2,752 million dollars to Tajikistan and 1,407 million dollars to Kyrgyzstan. The accumulated capital officially transferred by migrants, representing almost half of the GDP for Tajikistan ${ }^{69}$,appears today fundamental for the families and societies of Central Asia.

This dependence places migration at the forefront of inter-state relations (Figure 2). It takes the form of geopolitics from below, exploited by Russia, recognized and accepted by Kyrgyzstan and Tajikistan but hidden and rejected by Uzbekistan. The authorities of the country are keen to free themselves from post-colonial domination and are often perceived to have, in this context, a policy to limit labour migration, especially to their former metropole ${ }^{70}$. But despite geo-economic and geopolitical constraints linked to labourmigration on the international position of the country, the state indirectly encourages labour migration via the development strategies of national transport companies, which have sought toreinforce the route between Uzbekistan and Russia since the 2000s (Figure 1) ${ }^{71}$. At a time when states analyse the situation by confronting the pros and cons of this new migration flows within theeconomic, social and political arenas, this ambivalent attitude of Uzbekistan underlines the complexity of today's relations between Central Asia and Russia. Recent publications have not only describedthe new dependence of Central Asian societies but also raised the necessity for Russia to ensure a regular workforce flow. Thus one should be wary of univoqual approaches to geopolitical and geo- economic mutations stemming from labour migrations and strictly opposing North and South, post-imperial Russia against postcolonial Central Asian countries, and eager Russian businessmen against Central Asian 
workers, exploited and victims of racism. Firstly, the geographical diversification of labour migration, particularly through the migration flows from Uzbekistan and Kyrgyzstan to Kazakhstan, helps preserve Central Asia's exclusive relationship with Russia. Secondly, the generalization of socio-spatial differentiation mechanisms, socioeconomic hierarchy and geopolitical domination go beyond post-colonialism and affect all countries and societies, in the globalized post-Soviet region.

\section{Notes}

1. Bradshaw, M.J. (ed), Geography and Transition in the Post-Soviet Republics, Chichester: J. Wiley, 1997, 233 p.

2. Elissalde, B., 'Géographie, temps et changement spatial,' L'espace géographique, 2000, vol. 3, pp. 224236.

3. Thorez, J., Flux et dynamiques spatiales en Asie centrale. Géographie de la transformation postsoviétique, Thèse de doctorat, Université Paris 10 - Nanterre, 2005, 570 p.

4. Lacoste, Y., Géographie du sous-développement, Paris : PUF, 1965, 284 p. ; Chapuis, R., Brossard, T., Les quatre mondes du Tiers-Monde, Paris : Armand Colin, 1997, 247 p.

5. Brandt, W. (ed), Nord-Sud: un programme de survie, Paris: Gallimard, 1980, 535 p.

6. Beaucourt, C., Chambre, H., Miklasz, C., Tiers monde soviétique? Le Kazakhstan, Paris: Cahier de l'Institut de Science économique appliquée, 1963, 329 p. ; Maurel, M.-C., Territoire et stratégie soviétique, Paris: Economica, 1982, 196 p.; Blum, A., 'L'Asie centrale ex-soviétique, espace culturel et espace démographique,' Cahiers d'études sur la Méditerranée orientale et le monde turco-iranien, 1993, vol. 16, pp. 335-349.

7. Maurel, M.-C., 'Les logiques territoriales du pouvoir soviétique,' Bulletin de la société languedocienne de géographie, 1987, vol. 110, pp. 7-20.

8. Atlani-Duault, L., Lautier, B., 'Quand le second monde bascule au sud,' Revue Tiers Monde, 2008, vol. 193, pp. 5-11.

9. Nagels, J., La tiers-mondisation de l'ex-URSS?, Bruxelles: Éditions de l'université de Bruxelles, 1993, $226 \mathrm{p}$.

10. Nagels covers the whole of the post-Soviet world in his works written during the economic crisis at the beginning of the 1990s (Ibid.)

11. Doumenge, F., Enclavement et développement, Paris: Agence de coopération culturelle et technique, 1986, p. 92.

12. Laitin, D., Identity in Formation, the Russian-speaking Population in the Near Abroad, IthacaLondon: Cornell University Press, 1998, 417 p.

13. Zajončkovskaâ, Ž.A., Vitkovskaâ, G.S. (eds), Postsovetskie transformacii: otraženie v migraciâh [Post-Soviet transformations: in the Face of Migrations], Moscow: Adamant, 2009, 412 p. ; Laruelle, M. (ed), Dynamiques migratoires et changements sociétaux en Asie centrale, Paris: Pétra, 2010, 320 p.

14. EPEES (Laboratoire Espaces post-euclidiens et événements spatiaux), 'Événement spatial', L'espace géographique, 2000, vol. 3, pp. 193-199.

15. Sapir, J., Le Chaos russe, Paris: La Découverte, 1996, 329 p.

16. Trejviš, A.I., 'Geografiâ rossijskih krizisov' [A geography of Russian crises], Izvestiâ RAN - seriâ geografičeskâ̂, 1999, vol. 2, pp. 7-16.

17. Bertin, A., Clément, M., 'Pauvreté, pénurie et transition en Russie: de l'économie soviétique à l'économie de marché,' Revue d'études comparatives Est-Ouest, 2008, vol. 39/1, pp. 179-202.

18. From 1950 to 1973, annual economic growth averaged 4.5 per cent for Africa, 3 per cent for the United Kingdom and 5 per cent for France (Maddison, A., The World Economy: A Millennial Perspective, Paris: OECD, 2001,384 p.)

19. Lefèvre, C., 'Organismes internationaux et protection sociale en Russie,' Le Courrier des pays de l'Est, 2003, vol. 1040, pp. 16-25.

20. Raballand, G., 'Determinants of the Negative Impact of Being Landlocked on Trade: An Empirical Investigation through the Central Asian Case,' Comparative economic studies, 2003, vol. 45/4, pp. 520536.

21. Richard, Y., La Biélorussie, une géographie historique, Paris: L'Harmattan, 2002, 310 p.

22. Maurel, M.-C., 1982, Op. cit. ; Wild, G., 'De la politique d'aménagement du territoire à la logique de 
fragmentation,' in de Tinguy, A. (ed), L'effondrement de l'Empire soviétique, Bruxelles: Bruylant, 1998, pp. 277-296.

23. Nikol'skij, V.V., Geografiâ transporta SSSR [Geography of transport in the USSR], Moscow: Izdatel'stvo Moskovskogo Universiteta, 1978, 286 p.

24. Radvanyi, J., Le géant aux paradoxes - Fondements géographiques de la puissance soviétique, Paris: Messidor - Éditions sociales, 1982, $423 \mathrm{p}$.

25. Wild, G., Op. cit.

26. Maurel, M.-C., 1982, Op. cit.

27. Minc, A.A. (ed), Srednââ Aziâ. Èkonomiko-geografičeskâa harakteristika i problemy razvitiâ hozâjstva[Central Asia: Economic and geographical characteristics and problems of the development of the economy], Moscow: Mysl', 1969, 504 p.

28. Wild, G., Op. cit.

29. Blum, A., $O p$ cit. On the other hand, the relatively rapid decrease in mortality rates corresponded to a contemporary evolution of other Soviet regions.

30. However, at the onset of the First World War, western regions of the Tsarist Empire (Baltic Area, Poland, etc.) were more developed than the two-headed heart of European Russia. Among European empires, this situation was unique to Russian Empire. Kappeler, A., La Russie, empire multiethnique, Paris: Institut d'études slaves, 1996, 415 p.

31. Wild, G., Op. cit.

32. Maurel, M.-C., 1987, Op. cit.

33. Tašbaeva, T.H., Savurov, M.D, Novoe i tradicionnoe v bytu sels'koj sem'i Uzbekov [Novelty and tradition of rural Uzbek family lifestyles], Tashkent: Fan, 1989, 162 p.; Zûzin, D.I, 'Pričini nizkoj mobilnosti korennogo naseleniâ respublik Srednej Azii' [Causes of low level mobility of Central Asian populations], S Sociologičeskie issledovaniâ, 1983, vol. 1, pp. 109-118.

34. Carroué, L., Géographie de la mondialisation, Paris: A. Colin, 2004, 252 p.; Capdepuy, V., 'La limite Nord/Sud,'M@ppemonde, 2007, vol. 88 [http://mappemonde.mgm.fr/actualites/lim_ns.html]; AtlaniDuault, L., Lautier, B., Op. cit.

35. Trejviš, A.I., 1999, Op. Cit

36. Ibraeva, A.N., Kazbek, B.E., Puti i perspektivy mežregional'nogo vzaimodejstviâ v respublike Kazahstan [Regional cooperation paths and perspectives in Kazakhstan], Astana, 2010, 234 p.

37. In comparison, in France, GDP per capita per annum varies from 1 to 2 depending on the region, due to the dominance of Paris. Outside the Paris region (Ile-de-France), differences with the national average do not exceed 25 per cent.

38. Ibid.

39. Kolossov, V., O'Loughlin, J., 'How Moscow is becoming a Capitalist Mega-City,' International Social Sciences Journal, 2004, vol. 56/181, pp. 413-427.

40. Vendina, O., 'Social Polarization and Ethnic Segregation in Moscow,' Eurasian Geography and Economics, 2002, vol. 43/3, pp. 216-243.

41. Škaratan, O.I. (ed), Social'no-èkonomičeskoe neravenstvo i ego vozproizvodstvo v sovremennoj Rossii[Socio-economic inequalities and their reproduction in contemporary Russia], Moscow: Olma Media Group, 2009, 556 p.

42. Bret, B., Gervais-Lambony, P., Hancock, C., Landy, F. (eds), Justice et injustices spatiales, Paris: Presses Universitaire de Paris Ouest, 2010, 315 p.

43. Bradshaw, M.J., 'Observations on the Geographical Dimension of Russia's Resource Abundance,' Eurasian Geography and Economics, 2006, vol. 47/6, pp. 724-746.

44. Thorez, J., 'La construction territoriale de l'indépendance: réseaux et souveraineté en Asie Centrale post-soviétique,' Flux, 2007, vol. 70, pp. 33-48.

45. Zajončkovskaâ, Ž.A., Tûrûkanova, E.V., Florinskaâ, Û.F., Trudovâa migraciâ v Rossiû : kak dvigat'sâa dal'še?[Labour migrations to Russia: where to go from now?], Moscow: Maks Press, 2011, $52 \mathrm{p}$. [http://www.neweurasia.ru/media/1Labour_migration_to_Russia_r.pdf].

46. According to the Federal Migration Service, the number of officially registered migrant workers represents 3 per cent of the active population (Ibid.). Including illegal workers, the figure increases to almost 10 per cent, comparable to figures for Germany or Belgium.

47. Zajončkovskaâ, Ž.A., Mkrtčân, N.V., Tûrûkanova, E.V., 'Rossiâ pered vyzovami immigracii' [Russia and the call of immigration] in Zajončkovskaâ, Ž.A., Vitkovskaâ, G.S. (eds), Postsovetskie transformacii: otraženie v migraciâh, Moscow: Adamant, 2009, pp. 9-62.

48. Brusina, O., 'Migranty iz Srednej Azii v Rossii: ètapy i pričiny priezda, social'nye tipy, organizacii diaspor' [Migrants fromCentral Asian to Russia: migration stages and causes, social profiles and diaspora organisation], Vestnik Evrazii, 2008, vol. 2/40, pp. 66-95. 
49. Zûzin, D.I., Op. cit.;Tarasova, N.V., 'Problema povyšeniâ migracionnoj aktivnosti naseleniâ' [Problem of increased migration of the working population], in Sovremennye problemy migracii[Contemporary migration problems], Moscow: Mysl', 1985, pp. 47-63; Patnaik, A., 'Agriculture and Rural Out-migration in Central Asia (1960-1991),' Europe-Asia Studies, 1995, vol. 47/1, pp. 147-169.

50. Migration is not only an economic strategy. The works of M. Reeves reveal how the migratory experience has become an important element in masculine identity, to some extent replacing military service for the Red Army (Reeves, M., 'Migrations, masculinite et transformation de l'espace social dans la vallée de Sokh,' in Laruelle, M. (ed), Dynamiques migratoires et changements sociétaux en Asie centrale, Paris: Pétra, 2010, pp. 217-245). Further, these migration flows are nation-specific: Tajikikistan's legislation de facto encourages young men to migrate to avoid military service; in Uzbekistan, national migration restrictions linked to the administrative residents authorisation system (propiska), or business activities through the control and taxation of imported goods, encouraged migrations in the early 2000s with some business owners developing their international mobility experience (Sadovskaâ, E.Û., 'Kazahstan v central'noaziatskoj migracionnoj subsisteme' [Kazakhstan in the Central Asian migration sub-system], in Zajončkovskaâ Ž.A., Vitkovskaâ G.S. (eds), Op. cit., pp. 279-322).

51. Olimova, S.K., 'Tadžikistan: ot vynuždennoj k trudovoj migracii' [Tajikistan: from forced migrations to labour migrations], in Zajončkovskaâ, Ž.A., Vitkovskaâ, G.S. (eds), Op. cit., pp. 350-376 ; Maksakova, L.P., 'Uzbekistan v sisteme meždunarodnyh migracii' [Uzbekistan in the international migration system], in Zajončkovskaâ, Ž.A., Vitkovskaâ, G.S. (eds), Op. cit., pp. 323-349.

52. Thorez, J., 'La mobilité des migrants d'Ouzbékistan: transport, frontières et circulation migratoire,' Revue Européenne des Migrations Internationales, 2010, vol. 26/3, pp. 31-57.

53.Ibid.; Thorez J., 'Les nouvelles frontières de l'Asie Centrale: Etats, nations et régions en recomposition,' Cybergeo, 2011, 28 p. [http://cybergeo.revues.org/23707].

54. Zajončkovskaâ, Ž.A., Mkrtčân, N.V., Tûrûkanova, E.V., Op. cit.

55.Ibid.

56.Ibid.; Braux, A., 'Politique migratoire et gestion de la diversité culturelle en Russie: l'exemple de Moscou, 'Les études du CERI, 2009, vol. 158, 37 p.

57. Clochard, O. (ed), Atlas des migrants en Europe - Géographie critique des politiques migratoires, Paris: A. Colin, 2009, 144 p.

58. Thorez, J., 2010, Op. cit.; Thorez, J., 2011, Op. cit.

59. Thorez, J., 2010, Op. cit.

60. Tarhov, S.A., 'Transportnaâ integraciâ i dezintegraciâ postsovetskogo prostranstva: izmenenie passažirskih svâzej posle raspada SSSR' [Integration and disintegration of the transport system in the postSoviet space: changes to passenger lines after the break-up of the USSR], Izvestiâ RAN - seriâ geografičeskaâ, 1997, vol. 3, pp. 73-82; Kolossov, V.A. (ed), Geopolitičeskoe položenie Rossii: predstavleniâ $i$ realnost[The geopolitical situation of Russia: representations and reality], Moscow: Artkur'er - IGRAN, 2000, 352 p.; Thorez, J., 2005, Op. cit.

61. Thorez, J., 2007, Op. cit.

62. Thorez, J., 2005, Op. cit.

63. Ibid.

64. Tarhov, S.A., 1997, Op. cit.

65. Nikol'kij, V.V., 1978, Op. cit.

66. Thorez, J., 2010, Op. cit.

67. From 2000 to 2005 , the traffic of Russian airlines to Tajikistan increased from 6,000 to 274,000 passengers.

68. In some ways, the socioeconomic characteristics of Russian North Caucasus region are similar of those of South Caucasus countries. In Central Asia the main economic discontinuities are located, at international level, on the southern borders of Kazakhstan.

69. In Tajikistan, the share of remittances in GDP is the highest in the world, according to the World Bank. 70. Labour migrations can also be seen to reflect the incoherencies of the development model adopted since independence Laruelle, M., 2010, Op. cit.

71. Thorez, J., 2010, Op. cit. 
Figure 1: Uzbekistan Airways In-Flight Magazine

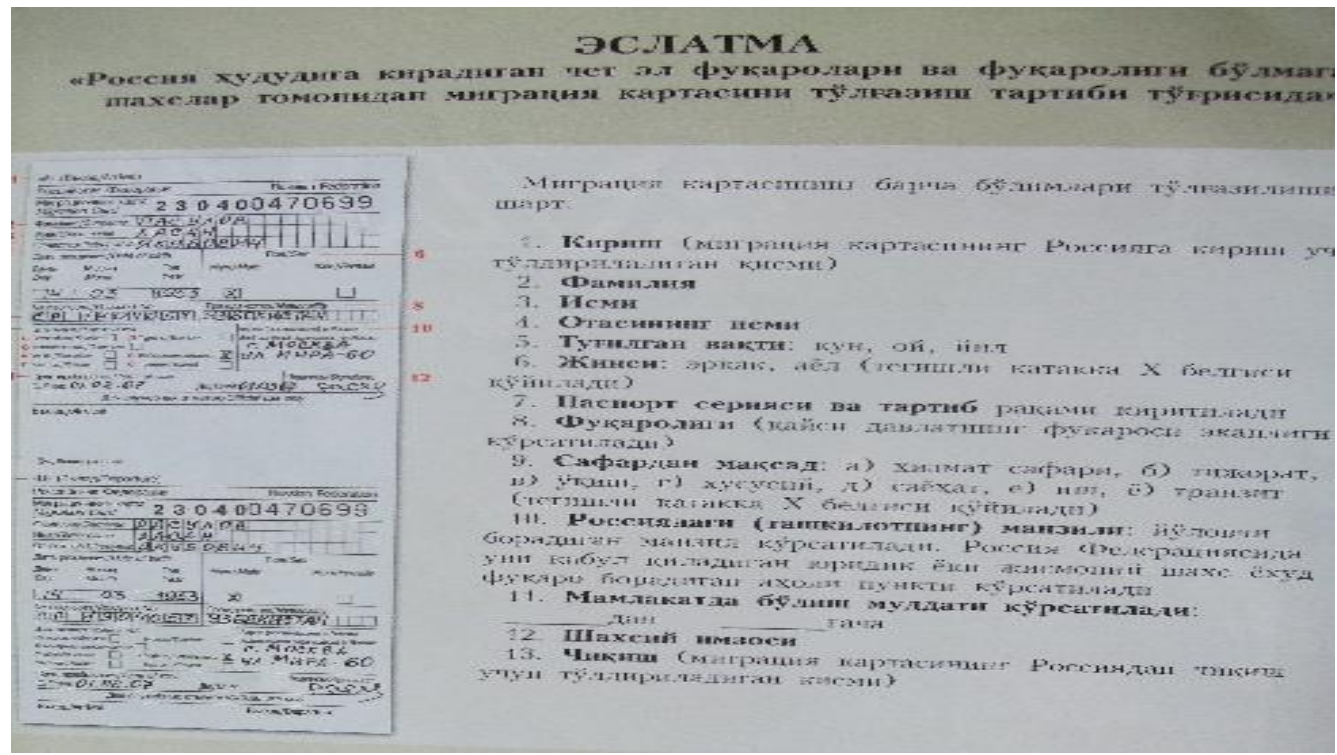

The in-flight magazine distributed by Uzbekistan Airways has a page to assist migrants with the administrative steps involved with arrival in Russia, highlighting the role of national companies in the transportation of workers from Uzbekistan. J. Thorez

Figure 2: Western Union Advertisement (Samarkand, Uzbekistan, 2006)

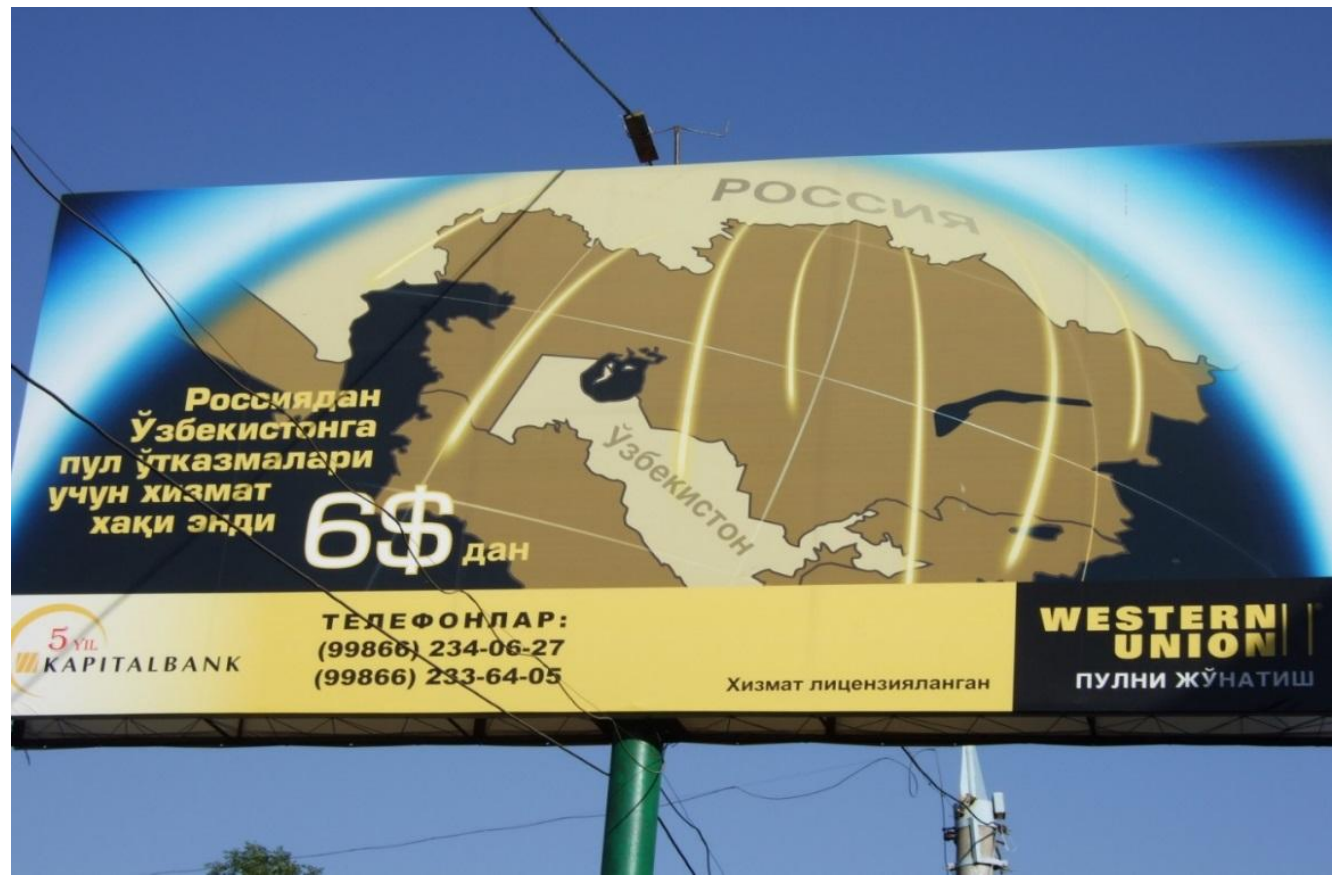

Both the subject and the graphics of this advertisement for a money transfer company reflect this asymmetric relation between Russia and Uzbekistan. J. Thorez. 
Map 1: GDP per Capita per Annum in 2010 (in Dollars)

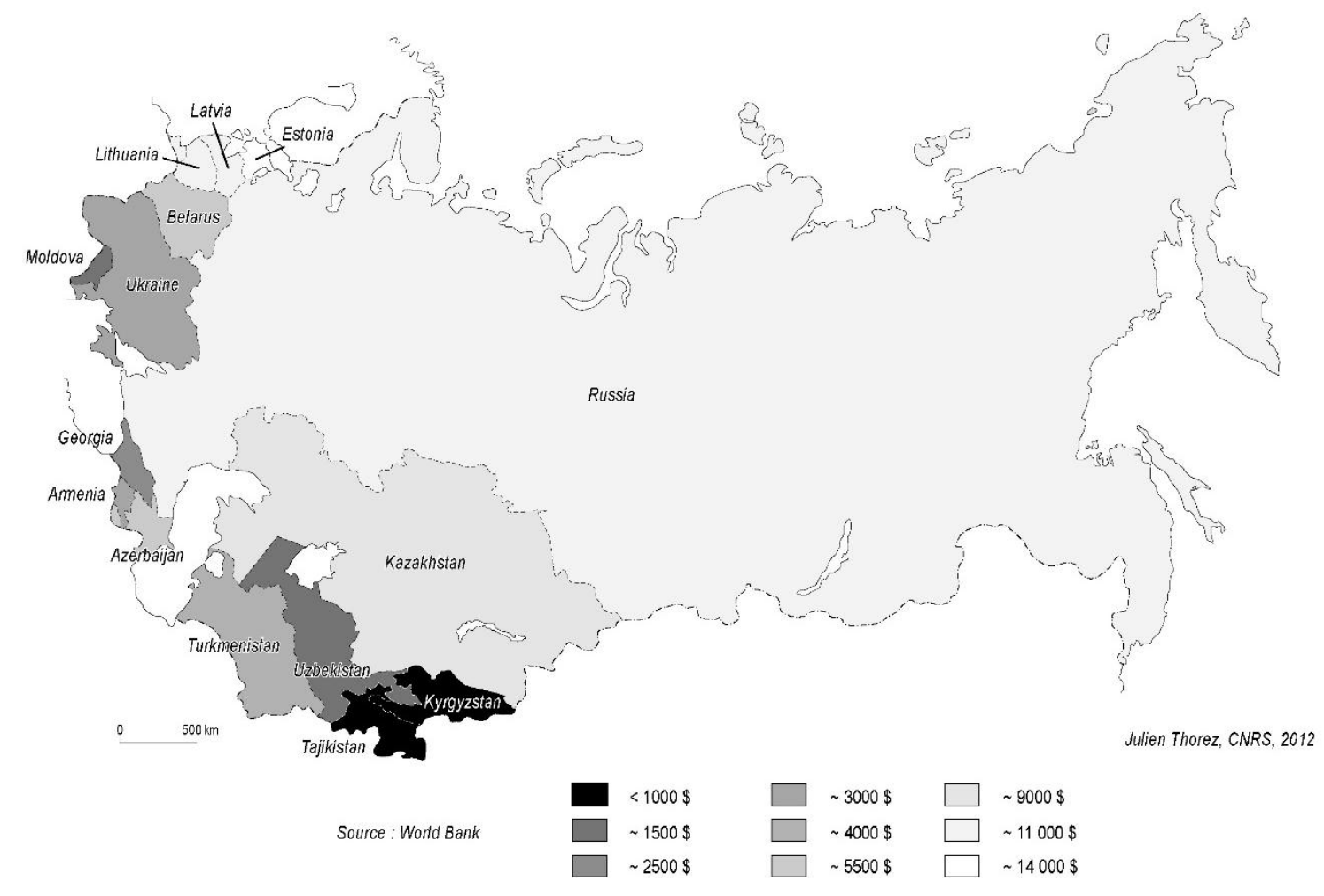


Map 2: Regular Air Links Between Uzbekistan and USSR in 1984 (Except Central Asia)

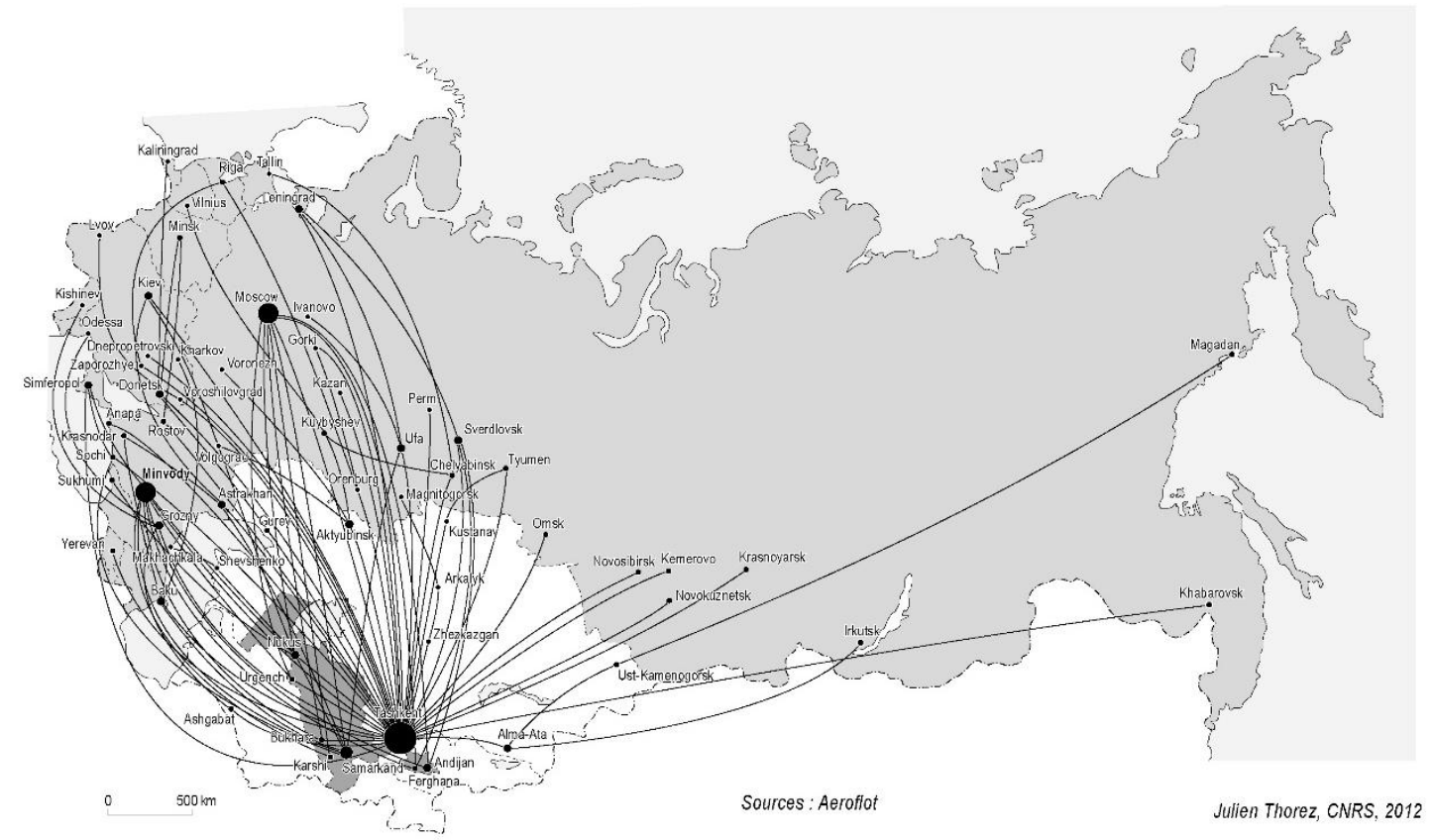

Map 3: Regular Air Links Between Tajikistan and USSR in 1984 (Except Central Asia)

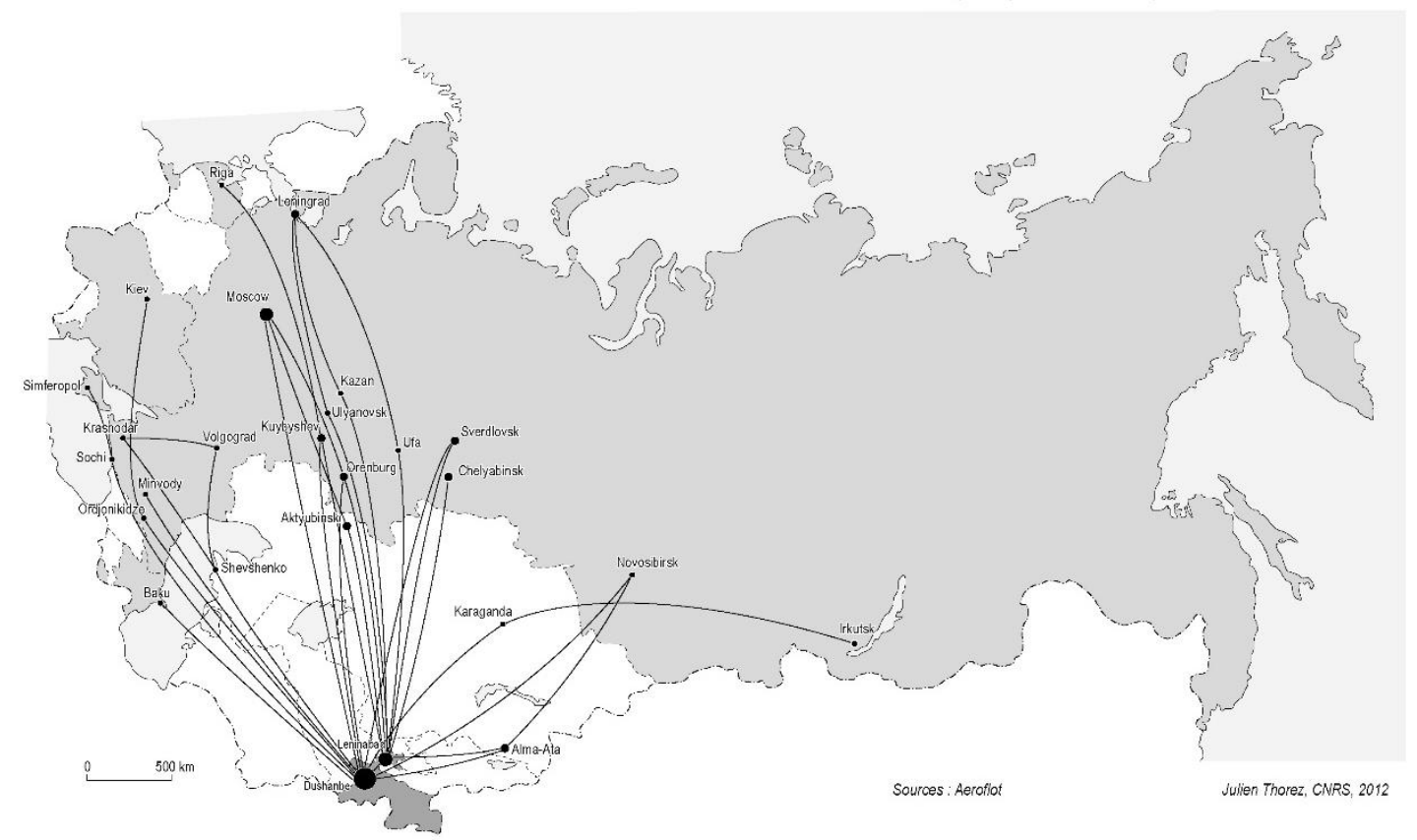


Map 4: Regular Air Links Between Uzbekistan and Former Soviet Union in 1996 (Except Central Asia)

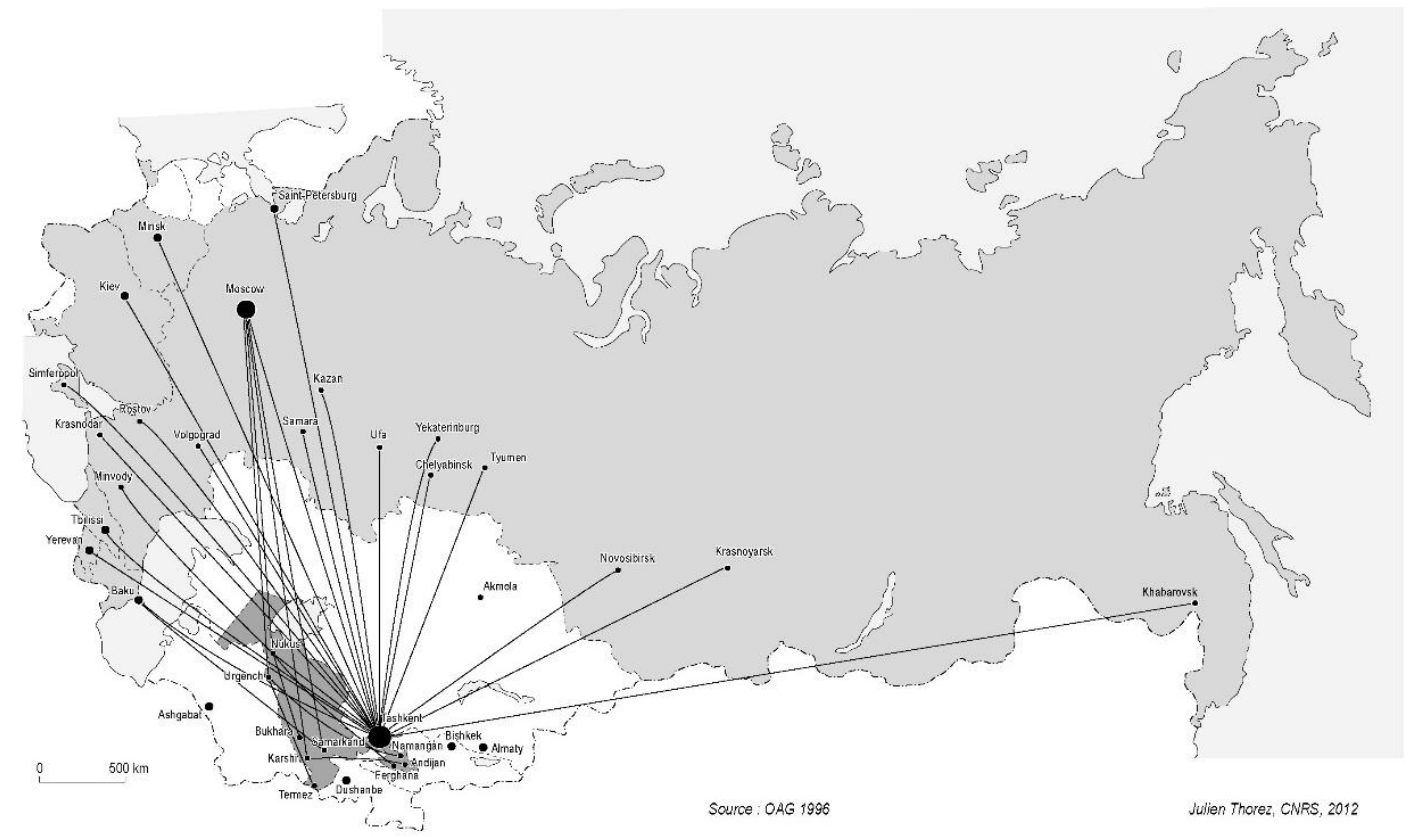

Map 5: Regular Air Links Between Tajikistan and Former Soviet Union in 1996 (Except Central Asia)

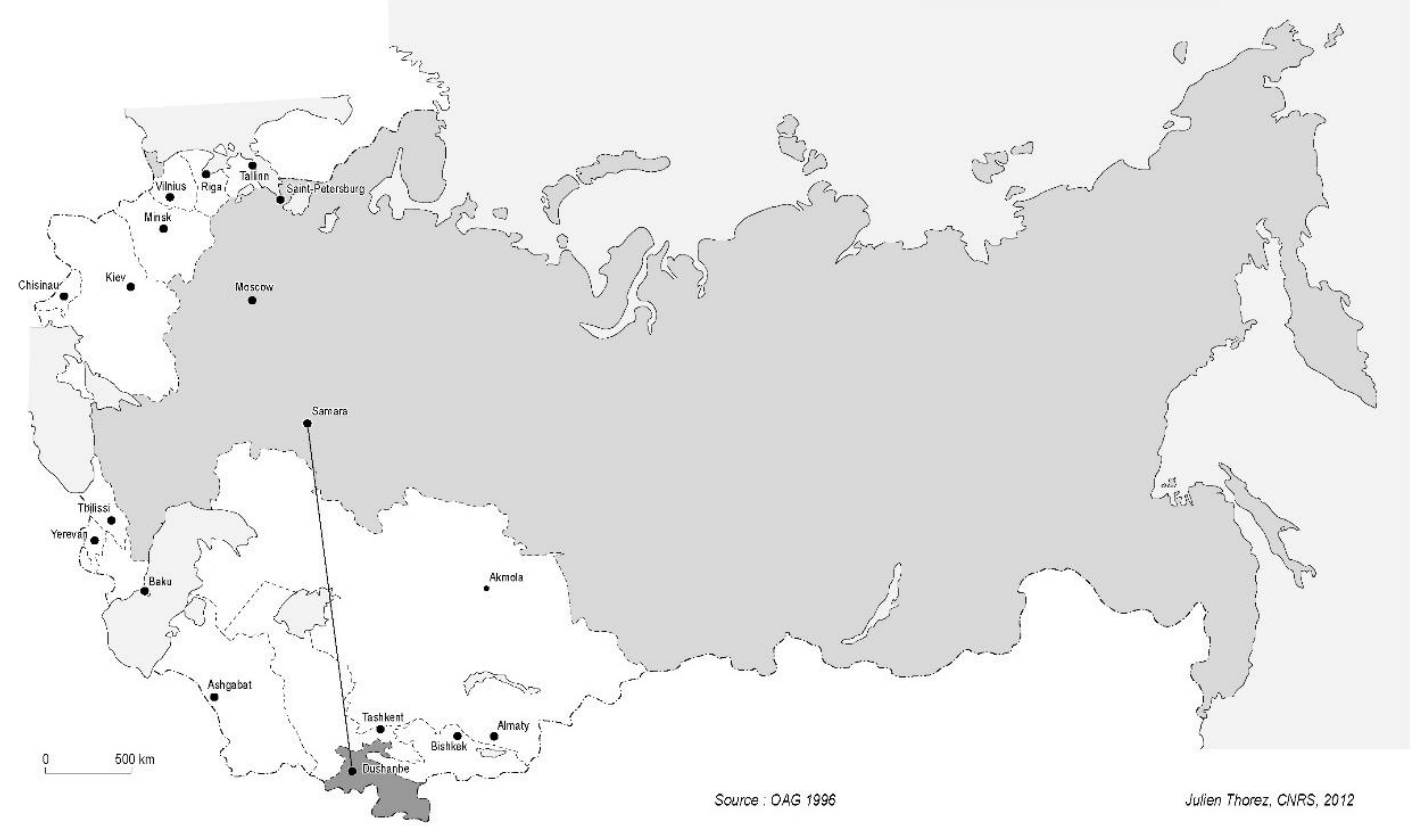


Map 6: Regular Air Links Between Uzbekistan and Former Soviet Union in 2008-2009 (Except Central Asia)

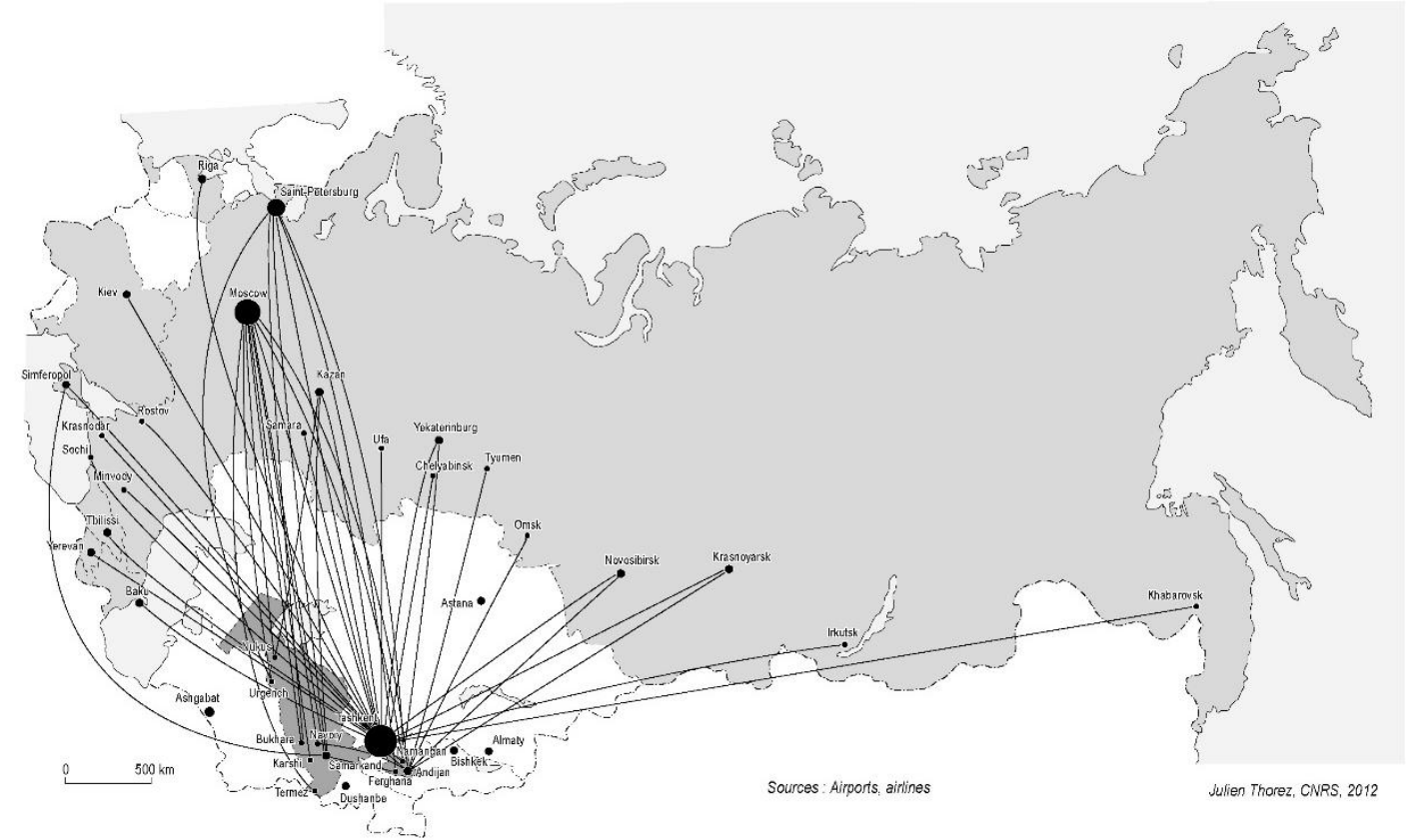

Map 7: Regular Air Links Between Tajikistan and Former Soviet Union in 2008-2009 (Except Central Asia)

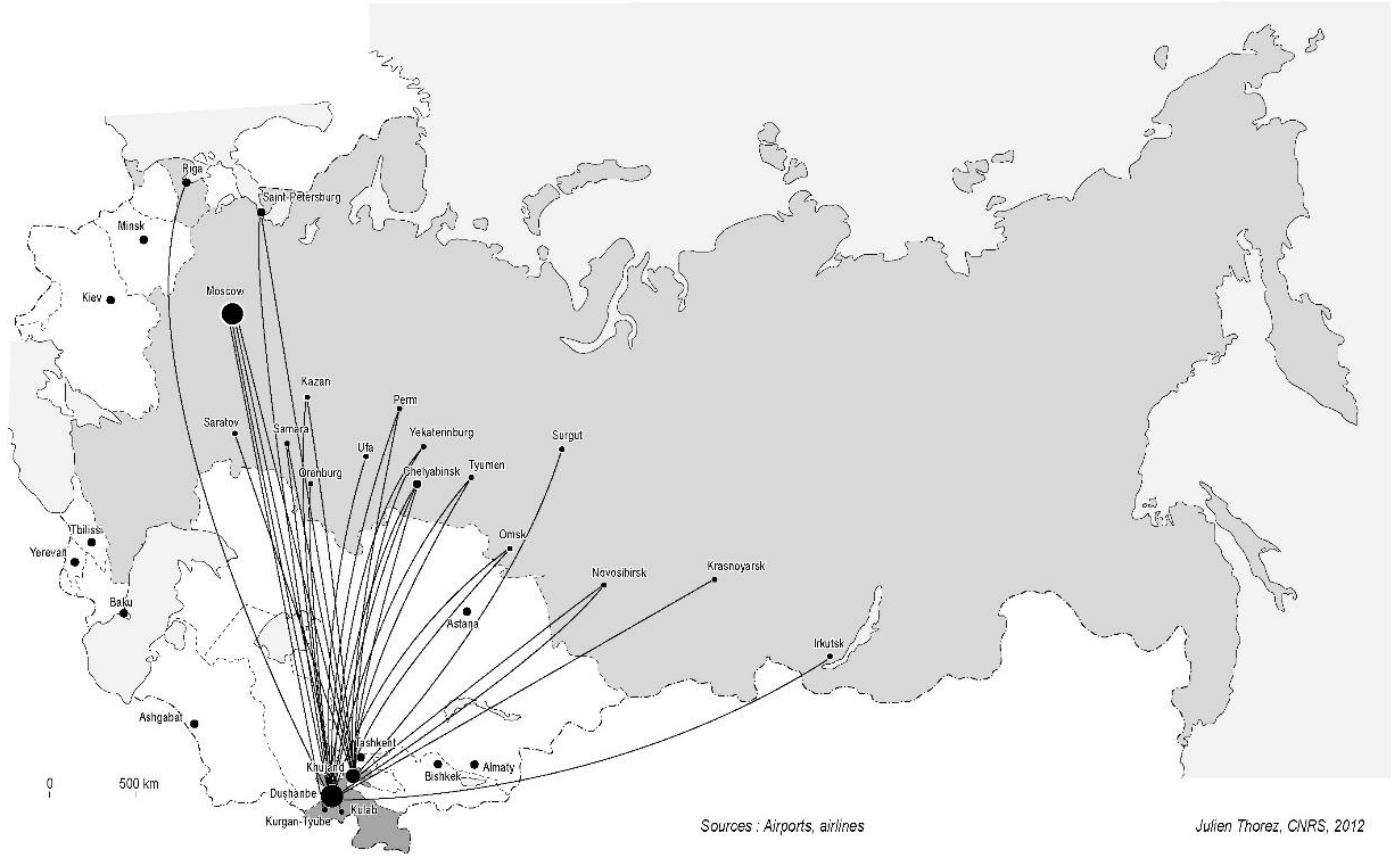

